\title{
MEDIATING ROLE OF ORGANIZATIONAL SILENCE ON THE EFFECT OF TRUST ON ORGANIZATIONAL COMMITMENT (CASE STUDY OF TEHRAN MUNICIPALITY)
}

\author{
Amani Saeed \\ M.A : Executive Management- on: Strategic Management, Science and Research Branch of Tehran, \\ Islamic Azad University, Tehran, Iran \\ Hamdi Karim \\ Associate Professor of Business Administration, management and Economy Faculty, Science and \\ Research Branch of Tehran, Islamic Azad University, Tehran, Iran
}

\begin{abstract}
The present research has been carried out with the aim of studying the mediating role of organizational silence on the effect of trust on organizational commitment. Its population includes all employees of Tehran Municipality with the size of 200 people. The sample size estimated to be 131 people using Cochran formula. For collecting data questionnaire is used. Cronbach alpha indicated the questionnaire reliability 0.87 . For analyzing data SEM is used in form of AMOS software. Findings indicate that organizational trust effects on organizational silence and organizational silence effects on organizational commitment but there is no significant relationship between organizational trust and organizational commitment.
\end{abstract}

Keywords: organizational silence, organizational commitment, organizational trust

\section{INTRODUCTION}

Lack of information and trust is one of main obstacles in succeeding programs and organizational objectives which is named as organizational silence (Zarei Matin, 2011). Morrison, and Milliken (2000) considers organizational silence as a social phenomenon in which employees prevent from expressing opinions and concerns about organizational problems. Employees have different motivations for keeping silent among which one can refer to silence according submission and admitting (satisfying silence) as well as self- protecting behavior based on fear (defensive fear) (Rhee, 2015)

For preventing from organizational silence and its optimal management, there is the need for creating trust in organization as one the most important social capital. This has brought about empathy among employees and administrative section managers (Marzughi et al, 2012). Hoy\& Tschannen-Moran (2003) believe that trust includes freedom of speech, honesty, reliability, benevolence and adequacy. Organizational trust includes two aspects of trust toward organization and trust toward supervisor (Tan and Tan, 2003) which effect on other organizational components.

On the other hand, majority of theorists and researchers agree that each organization success depends on employees' commitment, attachment, and faithfulness. In one hand, the aforementioned factors are helpful in solving problems such as Hypothyroidism, absence, replacement, and abandoning organization. On the other hand, a good ground will be created for increasing employees' efficiency by enhancing employees' internal motivations in order to attempt more and enhance the quality. Commitment is a psychological state which determines the employees' relationship with the organization and it refers to their decision for keeping membership in organization or cutting the cooperation (Chen and Francesco, 2003). Researches indicate that when employees believe that they can be involve in organizational issues, they are more willing not be silent, express their critics and solutions and to have the opportunity to influence on different levels of organization (Glew et al, 1995; Locke, and Schweiger , 1979). As a result, people try more than norm (duty) for organization 
success (Patchen, 1970; Martin et al, 1995) or in other words, these employees enjoy a higher level of commitment (Rhee, 2015).

Paying attention to human resources and organizational behavior factors such as trust, organizational silence as well as their relationship in municipality can bring about an increase in commitment among employees and as a result leads to higher efficiency for the organization. This results in more satisfaction from municipality services beside an optimal use of limited resources and improving Municipality performance as a service institution which is governed by government officials. Thus, municipality requires more commitment among employees to attract more satisfaction among customers and to increase efficiency and improve performance. Therefore, the present research main question would be:

"What is the role of organizational silence on the effects of trust on organizational commitment in Tehran Municipality?"

\section{THEORETICAL FRAMEWORK}

\section{SILENCE}

Morrison. and Milliken (2000) believe that silence is a powerful force in organizations which has not received enough attention and research. The reason behind not paying attention to silence is explained. Silence is the lack of behavior. When there is no behavior, discovering its related problems is difficult. In fact no body become worried about a behavior which do not exist.

According to Pinder and Harlos (2001) silence is a conscious, active and systematic behavior. When people do what they are being expected without expressing their thoughts, this can be a sign of complaining to organizational methods (Briensfield, 2013). Pinder and Harlos (2001) introduced silence and satisfying silence as two forms of silence and they compared these two forms with 8 aspects: voluntary, awareness, acceptance, stress level, being aware of alternative options, willing to express voice, wiling to express dominant feelings. (Pinder and Harlos, 2001) suggested that employees silence is a form of silence which indicates on purpose deletion. Therefore, they believe that silent employees conceal information according to some motivations.

Satisfying silence is an option for forgetting to follow everything (Pinder and Harlos , 2001). Those people with satisfying silence contrary to silent people are not willing to change their environment. Similarly, Van Dyneet al (2003) confirmed people' motivation of silence by a discussion of three types of silence: Resignation, fear and cooperation. Van Dyne et al (2003) has suggested defensive silence. Therefore, people follow satisfying silence regarding issues about work based on low efficiency in change. When a superior do not respond the presented information provided by his employees and prevents from employees' participation in discussions related to organizational issues, the employees assume speaking useless and accordingly they incline toward satisfying silence. Defensive silence is the prevention from expressing opinions and presenting information according to fear and self- protection (Van Dyne et al , 2003). Employees who are aware of punishment are fired from their works and they know that they would be labelled as a troublesome person and this way they protect themselves against negative consequences. Community- friendly (cooperative) silence is related to disclosing information related to work, opinions, and ideas with the aim of others' or organization benefits (Van Dyne et al , 2003). Satisfying and defensive silence have negative effects on organization but community friendly silence is not a harmful phenomenon for organization (Wang . and Hsieh , 2013).

\section{TRUST}

Interpersonal trust depends on individuals' characteristics and it is the result of repeated contacts among people while institution trust is evolved by structure relationship and developed rules in organization (Fox, 1974). Similarly, Tan and Tan (2000) indicated that although there is a positive relationship between trust to supervisor and trust to organization but they both have to be paid attention as two separate construct with different components and consequences. 
According to Tan and Tan (2000) trust to supervisor is deeply related to concepts such as capability, benevolence, supervisors integration and trust to organization has a positive relationship with world variables such as fair and organizational commitment. Employees may enjoy a higher level of trust to their supervisor while they enjoy a low level of trust to the organization since there can be a good relationship between employees and supervisors that at last brings about trust to supervisors (Tan and Tan, 2000). Trust to organization and trust to supervisor are considered two separate construct.

\section{TRUST TO ORGANIZATION AND SILENCE}

Organizational trust refers to people positive expectations regarding organization employees behaviors based on relationship, organizational role and mutual attachments (Shockley-Zalabak et al, 2000).

Trust to leaders and senior managers are positively related to employees' self -efficiency (Yang, and Mossholder , 2010). In other words, employees with higher trust to organization enjoy a higher selfefficiency in creating difference in the organization which enables them to share their concerns about establishing a different organization with others while those people with a lower level of trust enjoy a lower level of self- efficiency in presenting suggestions and solutions and they remain in a satisfying silence (Rhee, 2015). Those people who trust to their own organization are more likely self-confident about their behavior consequences and senior managers' reaction ( Detert, and Burris , 2007).

\section{TRUST TO SUPERVISOR AND SILENCE}

Mayer and., Davis (1995) model has discussed trustful and trustee person characteristics. Capability is a combination of skills, liabilities and features which create the opportunity for influencing in a certain range. Benevolence is adapted from individual's belief from helping to people. Honesty implies trustful quality and introduce him/ her as believing in a set of principles which are accepted for the one who trusts (Mayer, R. C., Davis , 1995). People evaluate supervisors' benevolence and integration before sharing any information since they have to make sure that the supervisors would not punish them for presenting those information. In case the supervisor is known for having a negative attitude toward sharing information, people will find a level lower than trust to their supervisor (Rhee, 2015).

Furthermore, when supervisors do not pay attention to the shared information by employees, employees will have a trust level lower than the trust to their supervisors and as a result, they feel that speaking do not incur any kind of changes. According such an interpretation, employees abandon their concerns regarding their work and this leads to a satisfying silence (Rhee, 2015).

\section{SILENCE AND ORGANIZATIONAL COMMITMENT}

As was mentioned before, those with satisfying silence do not express their concerns due to this belief that they can not make any changes and that is why they do not engage themselves in organizational issue (Van Dyne et al , 2003). When employees believe that they are engaged in organization issues (French et al, 1960) they are willing to express their voice even indirectly and they are also willing to have the opportunity to affect different levels of organization (Glew et al, 1995; Locke, and Schweiger , 1979). As a result, these people attempt more than their duty for organization success (Patchen, 1970; Martin et al, 1995). In contrast, those who have abandoned organizational issues are less likely to be committed to their organization (Aluttoand Belasco , 1972; Alutto, and Acito, 1974). Those with defensive silence conceal their concerns based on fear and threat. When individuals feel that their situation is endanger they are less likely committed (Wang, 2005). Tsai, and Young (2010) explores a negative relationship between risk and commitment. Also Deniz et al (2013) confirmed the negative relationship between defensive silence and organizational commitment. Therefore, we believe that those with defensive silence are less likely to be committed to their organization (Rhee , 2015).

\section{RESEARCH OBJECTIVES}

- Determining the effects of organizational trust on organizational silence 
- Determining the effects of organizational silence on organizational commitment

- Determining the effects of organizational trust on organizational commitment

1. Review if the related literature

Table 1. The review of related literature in and out of Iran

\begin{tabular}{|c|c|c|c|c|}
\hline No & Year & Researcher & Subject & Result \\
\hline 1 & 2015 & $\begin{array}{l}\text { Marzughi } \\
\text { et al }\end{array}$ & $\begin{array}{l}\text { The role of } \\
\text { organizational silence } \\
\text { in explaining the } \\
\text { relationship between } \\
\text { students trust to } \\
\text { managers and their } \\
\text { educational } \\
\text { satisfaction }\end{array}$ & $\begin{array}{l}\text { An increase in students trust level can } \\
\text { influence in reducing their silence. However, } \\
\text { reducing educational silence do not leads in } \\
\text { increasing educational satisfaction and } \\
\text { educational satisfaction can directly be } \\
\text { affected by students' trust to managers. } \\
\text { Therefore, students' trust to managers can } \\
\text { directly increase education satisfaction. }\end{array}$ \\
\hline 2 & 2014 & $\begin{array}{l}\text { Afshari et } \\
\text { al }\end{array}$ & $\begin{array}{l}\text { The relationship } \\
\text { between employees' } \\
\text { organizational } \\
\text { commitment and } \\
\text { organizational silence }\end{array}$ & $\begin{array}{l}\text { The more the silence phenomenon is in the } \\
\text { organization, the less the employees' } \\
\text { commitment would be }\end{array}$ \\
\hline 3 & 2012 & Salimi et al & $\begin{array}{l}\text { The effects of trust } \\
\text { components of } \\
\text { organizational trust in } \\
\text { creating organizational } \\
\text { commitment among } \\
\text { employees (Ardebil } \\
\text { city hospitals: a case } \\
\text { study) }\end{array}$ & $\begin{array}{l}\text { Local marketing has positive and significant } \\
\text { effect on creating organizational commitment. } \\
\text { Also according to Pearson correlation, all } \\
\text { local marketing components have positive and } \\
\text { significant relationship with organization } \\
\text { commitment. Perspective, improvement and } \\
\text { development do not enjoy an optimal status } \\
\text { among employees. Supervisor support has the } \\
\text { biggest portion in explaining organizational } \\
\text { commitment. }\end{array}$ \\
\hline 4 & 2012 & $\begin{array}{r}\text { Amir Kafi } \\
\text { and } \\
\text { Hashemi } \\
\text { Nasab }\end{array}$ & $\begin{array}{r}\text { The effects of } \\
\text { organizational justice, } \\
\text { perceived } \\
\text { organizational support } \\
\text { and organizational } \\
\text { trust on organizational } \\
\text { commitment }\end{array}$ & $\begin{array}{l}\text { Organizational justice effects indirectly on } \\
\text { commitment through two variables of } \\
\text { organizational support and organizational } \\
\text { trust. Perceived organizational support also } \\
\text { have direct and indirect effects on } \\
\text { commitment. Its indirect effects is done } \\
\text { through organizational trust variable and } \\
\text { finally the direct effects of organizational trust } \\
\text { on commitment is more than the effects of } \\
\text { other variables. }\end{array}$ \\
\hline 5 & 2009 & $\begin{array}{l}\text { Khanifer et } \\
\text { al }\end{array}$ & $\begin{array}{l}\text { The relationship } \\
\text { between employees' } \\
\text { trust and } \\
\text { organizational } \\
\text { commitment ( in } \\
\text { Agricultural Jihad } \\
\text { organization and Qom } \\
\text { Education office) }\end{array}$ & $\begin{array}{l}\text { In both organizations there is no significant } \\
\text { relationship between employees' commitment } \\
\text { and trust. Furthermore, there is a significant } \\
\text { relationship between attention and emotional } \\
\text { commitment, attention and Normative } \\
\text { commitment. }\end{array}$ \\
\hline
\end{tabular}




\begin{tabular}{|c|c|c|c|c|}
\hline 6 & 2015 & Rhee & $\begin{array}{r}\text { The relationship } \\
\text { between trust, silence } \\
\text { and organizational } \\
\text { commitment }\end{array}$ & $\begin{array}{l}\text { Trust to organization has negative effects on } \\
\text { satisfying silence but it is no significant } \\
\text { effects on defensive silence. Trust to } \\
\text { supervisor has no significant effects on } \\
\text { satisfying silence while it has negative effects } \\
n \text { defensive silence. Also satisfying silence } \\
\text { and defensive silence have negative effects on } \\
\text { organizational commitment. }\end{array}$ \\
\hline 7 & 2013 & Deniz et al & $\begin{array}{r}\text { The relationship } \\
\text { between employees } \\
\text { silence and } \\
\text { organizational } \\
\text { commitment in a } \\
\text { private healthcare } \\
\text { company }\end{array}$ & $\begin{array}{l}\text { There is a negative and significant } \\
\text { relationship between emotional commitment } \\
\text { and one aspect of organizational silence } \\
\text { (defensive silence) }\end{array}$ \\
\hline 8 & 2010 & $\begin{array}{r}\text { Tsai and } \\
\text { Young }\end{array}$ & $\begin{array}{r}\text { Anger, fear and } \\
\text { commitment } \\
\text { enhancement }\end{array}$ & $\begin{array}{l}\text { The research indicates that all negative } \\
\text { feelings reduce commitment. }\end{array}$ \\
\hline
\end{tabular}

\section{METHODOLOGY}

The present research is a practical, descriptive survey. The population comprises of 200 employees of Tehran municipality. The sample size is estimated 131 using Cochran formula. The sample is selected randomly. For collecting data questionnaire is used which includes 5 questions for measuring trust to organization (Cummingsand Bromiley, 1996), 7 questions for measuring trust to supervisor (Robinson, 1996), 10 questions for measuring organizational silence ( Van Dyne et al, 2003) and 5 questions for measuring organizational commitment ( $\mathrm{T}$ sui et al, 1997). For measuring the items, 5 items Likert scale (completely agree - completely disagree) was used. Questionnaire Cronbach alpha is equal to 0.87 which indicates its high reliability. The questionnaire validity is also confirmed by professors and experts.

\section{HYPOTHESIS AND THE RESEARCH MODEL RESEARCH HYPOTHESIS}

- Organizational trust effects on organizational silence

- Organizational silence effects on organizational commitment

- Organizational trust effects organizational commitment 


\section{RESEARCH MODEL}

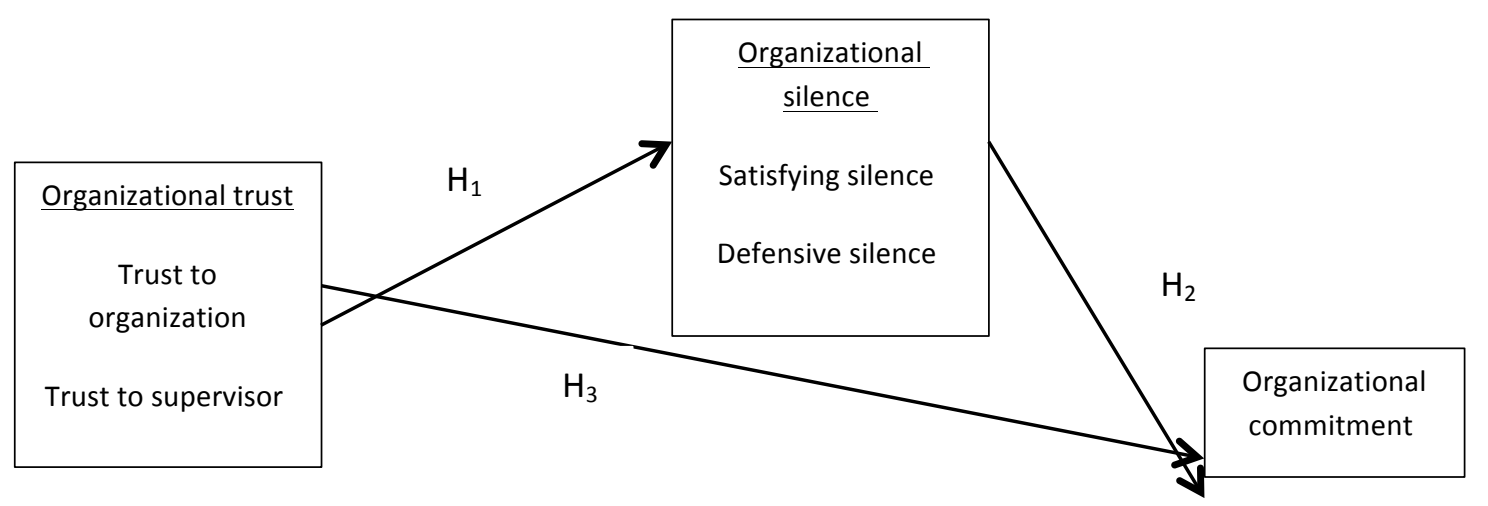

Figure 1. the research conceptual model

DATA ANALYSIS

DESCRIPTIVE STATISTICS

Table 2. results from demographic statistics

\begin{tabular}{|c|c|c}
\hline \multicolumn{2}{c}{ Demographic variables } & Frequency \\
\hline \multirow{4}{*}{ Job experience } & 5 years and less & $19 \%$ \\
\cline { 2 - 3 } & $5-10$ years & $26.71 \%$ \\
\cline { 2 - 3 } & $10-15$ years & $38.16 \%$ \\
\cline { 2 - 3 } & 15 years and more & $17.55 \%$ \\
\hline \multirow{5}{*}{ Education } & Diploma and less & $0 \%$ \\
\cline { 2 - 3 } & Assistant degree and bachelor & $67 \%$ \\
\cline { 2 - 3 } & Master degree and more & $33 \%$ \\
\hline \multirow{5}{*}{ Age } & $20-30$ years & $25 \%$ \\
\cline { 2 - 3 } & $31-40$ years & $40 \%$ \\
\cline { 2 - 3 } & 41 and more & $35 \%$ \\
\hline Gender & Female & $41.5 \%$ \\
\cline { 2 - 3 } & Male & $58.5 \%$ \\
\hline
\end{tabular}

Table 3. Descriptive statistics of organizational commitment

\begin{tabular}{|c|c|c|c|c}
\hline Variable & Minimum & Maximum & Average & $\begin{array}{c}\text { Standard } \\
\text { deviation }\end{array}$ \\
\hline $\begin{array}{c}\text { Organizational } \\
\text { commitment }\end{array}$ & 1.4 & 4.4 & 2.97 & 0.58 \\
\hline
\end{tabular}

Table 4. Descriptive statistics of organizational silence

\begin{tabular}{|c|c|c|c|c}
\hline Variable & The least value & The most value & Average & $\begin{array}{c}\text { Standard } \\
\text { deviation }\end{array}$ \\
\hline Voluntary silence & 1.6 & 4.2 & 2.9 & 0.58 \\
\hline Defensive silence & 1.6 & 1.8 & 3.1 & 0.55 \\
\hline $\begin{array}{c}\text { Organizational } \\
\text { silence }\end{array}$ & 1.6 & 4.4 & 3.07 & 0.52 \\
\hline
\end{tabular}

Table 5. Descriptive statistics of organizational trust

\begin{tabular}{|c|c|c|c|c}
\hline Variable & Minimum & Maximum & Average & $\begin{array}{c}\text { Standard } \\
\text { deviation }\end{array}$ \\
\hline $\begin{array}{c}\text { Trust to } \\
\text { organization }\end{array}$ & 1.2 & 4.8 & 3.07 & 0.53 \\
\hline
\end{tabular}




\begin{tabular}{|c|c|c|c|c}
\hline $\begin{array}{c}\text { Trust to } \\
\text { supervisor }\end{array}$ & 2 & 5 & 3.38 & 0.59 \\
\hline $\begin{array}{c}\text { Organizational } \\
\text { trust }\end{array}$ & 1.74 & 4.5 & 3.23 & 0.52 \\
\hline
\end{tabular}

\section{INFERENTIAL STATISTICS}

\section{RELIABILITY STATUS}

For measuring questionnaire reliability Cronbach alpha is used in form of SPSS. According to table 6 variables reliability and the whole questionnaire reliability is assumed to be at an optimal level.

Table 6. Reliability status

\begin{tabular}{|l|l|l|}
\hline Variable & Cronbach alpha & Reliability status \\
\hline Organizational trust & 0.82 & High reliability \\
\hline Trust to supervisor & 0.84 & High reliability \\
\hline Voluntary silence & 0.83 & High reliability \\
\hline Defensive silence & 0.83 & High reliability \\
\hline Organizational commitment & 0.89 & High reliability \\
\hline The whole questionnaire & 0.87 & High reliability \\
\hline
\end{tabular}

CONFIRMATORY FACTOR ANALYSIS

Confirmatory factor analysis is used for analyzing the questionnaire internal structure and exploring each construct or variable components. Images 1 and 2 indicates first and the last stage of confirmatory factor analysis of the model. 


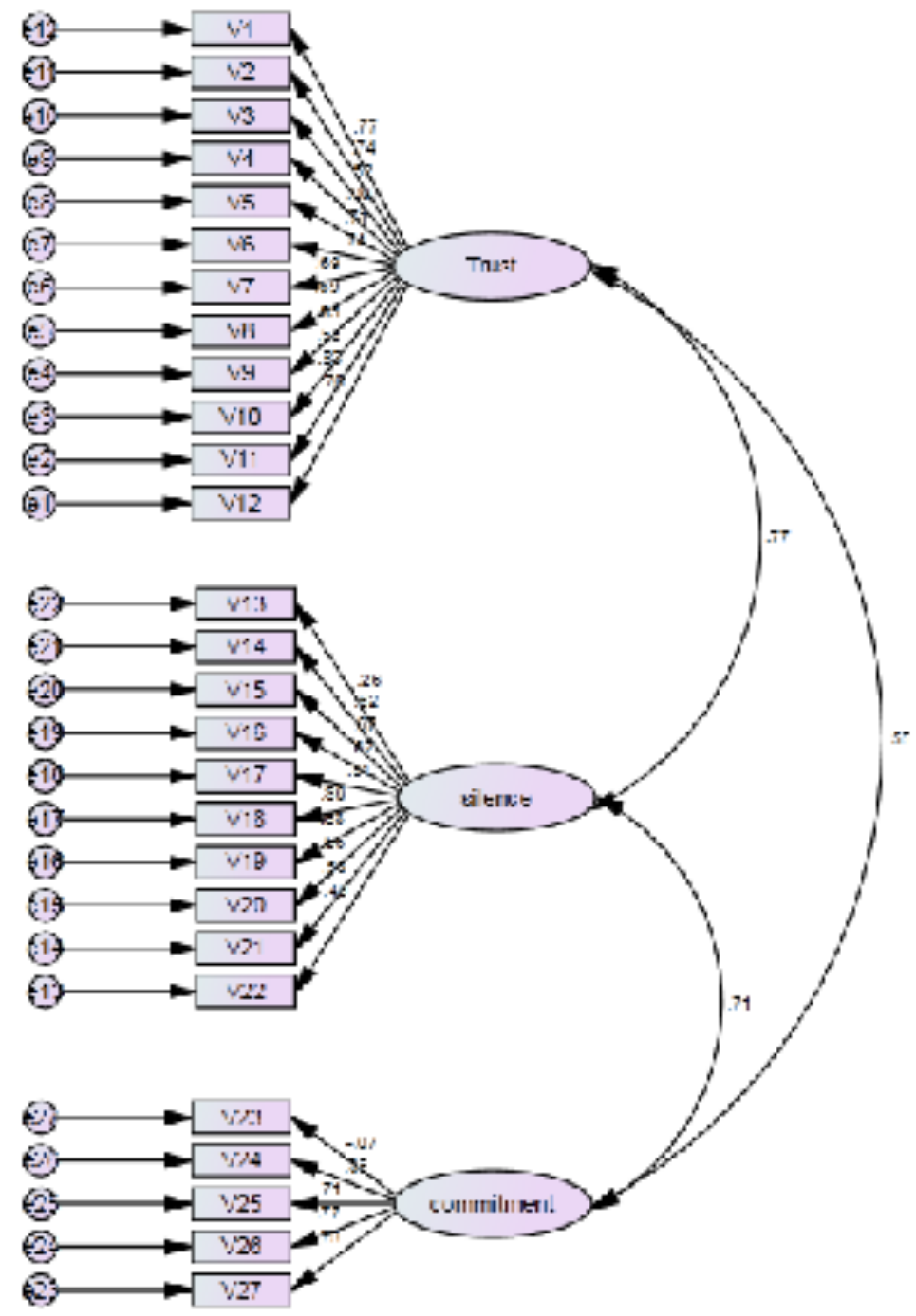

Image 1. The research model in standard estimation state 


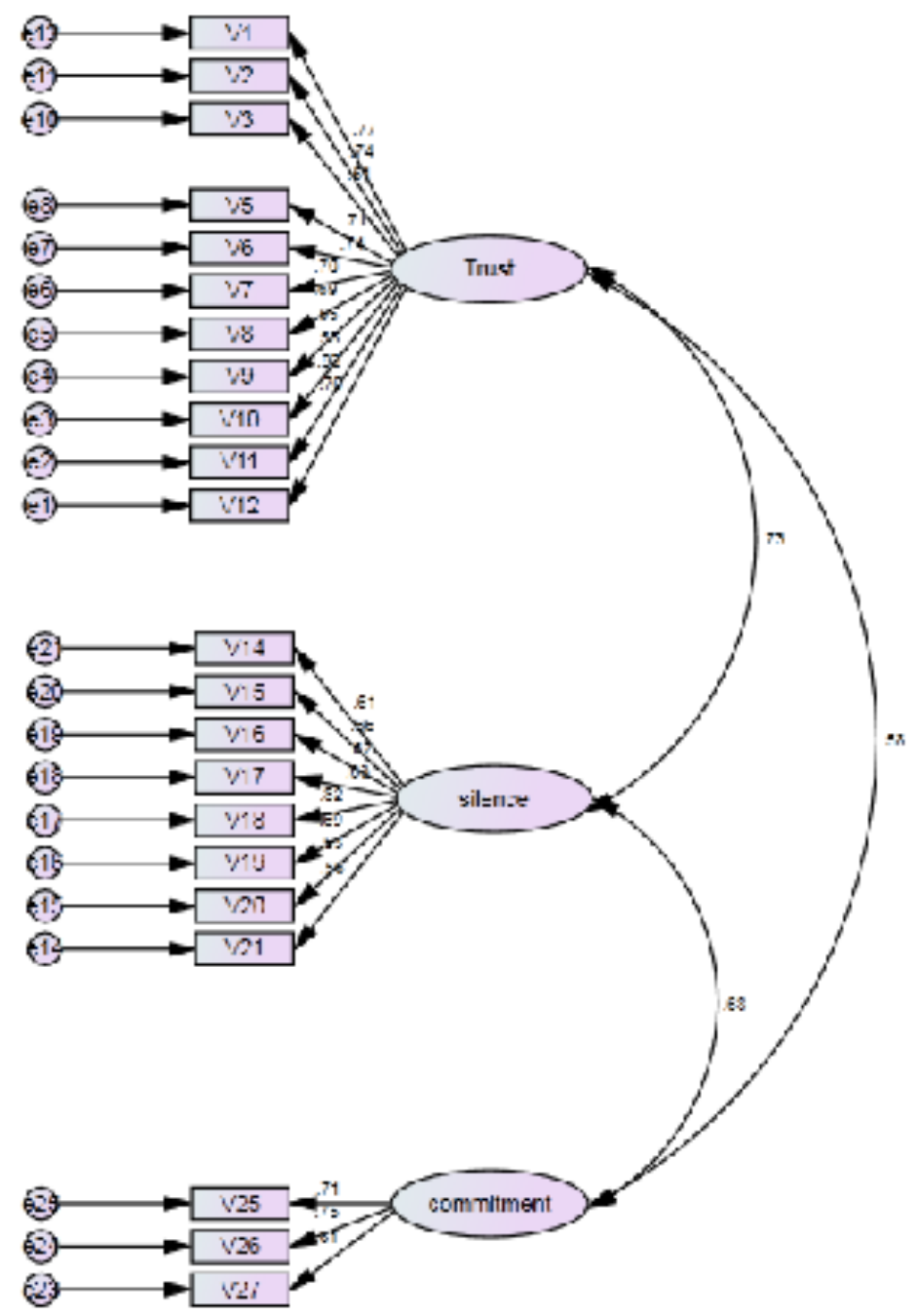

Image 2. The research model in significant level

\section{EVALUATING THE MODEL FITTING}

For evaluating the model fitting, three categories of fitting indices are used: absolute fitting index, comparative fitting index, reduced fitting index (Pahlavan Sharif and Mahdavian, 2015). Table 7 indicates fitting indices.

Table 7. fitting indices

\begin{tabular}{|c|c|c|c|c|c|c|}
\hline \multicolumn{2}{|c|}{ Reduced fitting indices } & \multicolumn{2}{|c|}{ Comparative fitting indices } & \multicolumn{3}{|c|}{ Absolute fitting indices } \\
\hline \multicolumn{2}{|r|}{ Allowed value } & \multicolumn{2}{|c|}{ Allowed value } & \multicolumn{3}{|c|}{ Allowed value } \\
\hline$<0.5$ & $<0.5$ & $<0.9$ & $<.09$ & $\begin{array}{r}\mathrm{p}- \\
\text { value }>.05\end{array}$ & $<5$ & $<0.1$ \\
\hline PCFI & PNFI & NFI & CFI & $\mathrm{K} 2$ & CMIN/DF & RMSEA \\
\hline .654 & .587 & .959 & .934 & 458.125 & 2.224 & .097 \\
\hline
\end{tabular}


As the fitting indices are shown to be in an allowed range, the model enjoys a good fitting.

\section{STRUCTURAL EQUATION MODEL ANALYSIS}

After testing the measuring model and measuring its validity using confirmatory factor analysis, we can investigate the relationship between the variables based on structural model. Image 3 indicates the research SEM model.

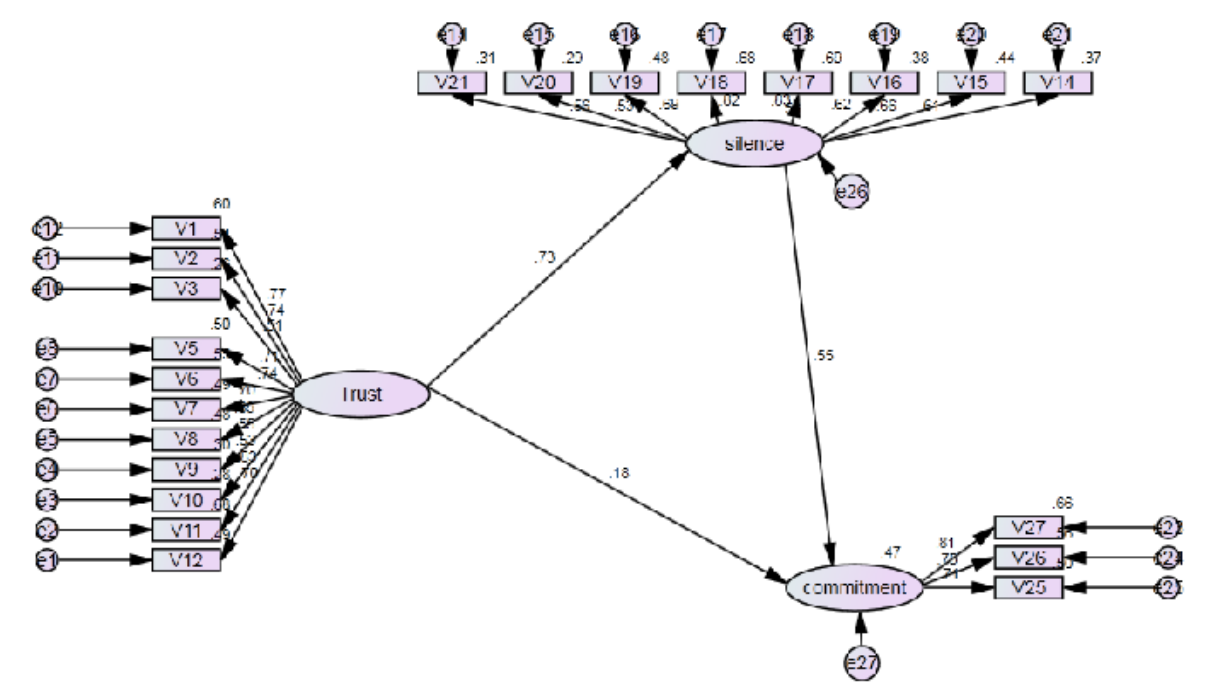

Image 3. SEM model based on CFA model results with optimal fitting

According to the table of regression weights in case crisis coefficient (C.R) is more than 1.96, then the relationship between the two variables are significant with the confidence of $95 \%$. Also in case pvalue is less than 0.05 , the relationship between the two variables is significant with the confidence of $95 \%$.

Table 8. response to hypotheses

\begin{tabular}{|r|r|r|r|r|r}
\hline Variables & $\begin{array}{r}\text { Non- standard } \\
\text { coefficient }\end{array}$ & S.E & C.R & P-value & Accept/ reject \\
\hline $\begin{array}{r}\text { Trust- } \\
\text { organizational } \\
\text { silence }\end{array}$ & 0.745 & 0.122 & 6.125 & 0.000 & Accepted \\
\hline $\begin{array}{r}\text { Organizational } \\
\text { silence- } \\
\text { organizational } \\
\text { commitment }\end{array}$ & 0.592 & 0.159 & 3.710 & 0.000 & Accepted \\
\hline $\begin{array}{r}\text { Organizational } \\
\text { trust- } \\
\text { organizational } \\
\text { commitment }\end{array}$ & 0.2 & 0.149 & & 0.178 & Accepted \\
\hline
\end{tabular}

\section{MULTIPLE CORRELATION SQUARE COEFFICIENT ANALYSIS}

This coefficient studies the capability of predicting dependent variable by variable or independent variables. It explains the percentage of dependent variable changes by independent variables. As multiple correlation square coefficient for organizational commitment is equal to 0.474 and 0.531 for 
organizational silence, therefore, $47.4 \%$ of knowledge management variable variance and $53.1 \%$ of learning attitude variable variance is explained by the model.

\section{CONCLUSION AND SUGGESTIONS}

Results indicate that the most frequency is related to male group with the frequency of $58.5 \%$ and male group with the frequency of $41.5 \%$ is in the second order. The most frequency is related to the age group of $31-40(40 \%)$. After than there is the age group of 41 years and more $(35 \%)$ and the least frequency is related to $20-30$ years $(25 \%)$. The most frequency $(67 \%)$ is related to the group of assistant degree and bachelor and after that there is the group of master degree and $\mathrm{PhD} \mathrm{(33 \% ).} \mathrm{Also} \mathrm{it}$ became clear that none of the employees have diploma or less degrees. The most frequency is related to the ones with the job experience of 10-15 years (38.16\%) and after that there is the group of those with job experience of 5-10years $(26.71 \%)$. Those with job experience of 5 years and less are in the third place $(19 \%)$ and the respondents with the job experience of 15 years and more $(17.55 \%)$ is in the last place.

According to descriptive statistics the average of variables for organizational commitment is equal to $2.97 \%$, organizational silence is equal to $3.07 \%$ and organizational trust is equal to $3.23 \%$. As the mentioned values are close to the theoretical average of the measuring scale, these values are evaluated as average.

In regard to accepting the first hypothesis it is suggested that managers of Tehran municipality should increase sincere, courteous and friendly behavior with employees to increase trust to organization. They also have to increase skills and knowledge among employees to increase employees' success. Therefore, managers of human resources can help employees by training classes. Also by selecting appropriate people for the positions of managers and supervisors the component of trust to supervisor can be encouraged. In case managers and supervisors are well aware of schedules and duties, they are more likely behave persistently. Also training classes and communicative skills for managers and increasing the use of transformational leadership style can help to increase trust among employees. Re the acceptance of second hypothesis managers and officials can help in increasing organizational commitment through decreasing organizational silence. In this regard an attendance system for employees make them sure that expressing their opinions and critics do not endanger them. Also a reward and encouragement system as well as opinion evaluation system can encourage employees to present creative solutions. In case all people become aware of the operationalization of other employees suggestions and solutions, employees will become aware of the importance of their words for the managers and therefore, organizational silence decreased. Re, the third hypothesis, as the effects of trust on commitment is rejected, it is suggested that managers take action for improving that in the organization to use the advantages of organizational trust. They also have to take action for increasing organizational commitment with other organizational parameters such as organizational silence or increasing job satisfaction.

\section{REFERENCES}

Afshari, Ali Asghar, Nasrin Rostam Beigi and Ameneh Nazari (2014), The relationship between employees' organizational commitment and organizational silence, the first conference of economics and practical management with a national approach.

Amir Kafi, Mehdi and Hashemi Nasab, Fakhrosadat (2012), The effects of organizational justice, perceived organizational support and organizational trust on organizational commitment

Pahlavan Sharif, Said and Mahdavian, Vahid (2015), structural equations modeling using AMOS, Bisheh Pub: Tehran

Khanifer, Hossein, Moghimi, Seyed Mohammad, Jandaghi, Gholamreza and Zarvandi, Nafiseh (2009), The relationship between employees' trust and organizational commitment ( in Agricultural Jihad organization and Qom Education office)

Zarei Matin, Hassan, Taheri, Fatemeh, Sayar, Abolghasem (2011), organizational silence: concepts, reasons and consequences, Iran Management sciences quarterly, 6(21), Pp 77- 104

Salimi, Yunes, Mohammad Bashokuh and Mohammad Hassan zadeh (2014), The effects of trust components of organizational trust in creating organizational commitment among employees (Ardebil 
city hospitals: a case study), the first international conference of economics, management, accounting and social sciences.

Marzughi, Rahmatolah, Heidari, Masumeh, Keshavarzi, Fahimeh, Heidari, Elham (2015), The role of organizational silence in explaining the relationship between students trust to managers and their educational satisfaction, education development journal in medical sciences, 8(17), Pp102- 114

Alutto, J.A. and Belasco, J.A. (1972), "A typology for participation in organizational decision making', Administrative Science Quarterly, Vol. 17, pp. 117-125.

Alutto, J.S. and Acito, F. (1974), "Decision participation and sources of job satisfaction: a study of manufacturing personnel", Academy of Management Journal, Vol. 12, pp. 160-167.

Briensfield, C, T. (2013) "Employee silence motives: Investigation of dimensionality and development of measures", Journal of Organizational Behavior, Vol. 34, pp. 671-697

Chen, Zhen Xiong and Francesco, Anne Marie (2003) "The Relationship Between the three Components of Commitment and Employee Performance in China", Journal of Vocational Behavior, 26: $490-510$.

Cummings, L.L. and Bromiley, P. (1996), "The organizational trust inventory (OTI): Development and validation", in Cummings, L.L. and Bromiley, P. (Eds), Trust in Organization, Sage, Thousand Oaks, CA.

Deniz, N., Noyan, A. and Ertosun, O. (2013), "The relationship between employee silence and organizational commitment in a private healthcare company", Procedia - Social and Behavioral Sciences, Vol. 99, pp. $691-700$.

Detert, J., R. and Burris, E., R. (2007), "Leadership behavior and employee voice: Is the door really open?" Academy of Management Journal, Vol. 50, pp. 869-884.

Fox, A. (1974), Beyond Contract: Work, Power, and Trust Relations. Faber \& Faber, London.

French, J.R.P. J, Israel, J. and As, D. (1960), “An experimental study on participation in a Norwegian factory", Human Relations, Vol. 13, pp. 3-19.

Glew, D.J., O’Leary-Kelly, A.M., Griffin, R.W. and Van Fleet, D.D. (1995), “Participation in organizations: a preview of issues and proposed framework for future analysis", Journal of Management, Vol. 21 pp. 395-421

Hoy, W. K. \& Tschannen-Moran, M. (2003). The conceptualization and measurement of faculty trust in schools: The omnibus T-Scale. In W.K. Hoy \& C.G. Miskel, Studies in Leading and Organizing Schools (pp. 181-208). Information Age Publishing: Greenwich: CT.

Knoll, D. and Gill, H. (2011), "Antecedents of trust in supervisors, subordinates, and peers", Journal of Managerial Psychology, Vol. 26, pp. 313- 330.

Locke, E.A. and Schweiger, D.M. (1979), "Participation in decision making: one more look", in Staw, B.M. (Ed.), Research in Organizational Behavior, Vol. 1, JAI Press, Greenwich, CT, pp. 266340 .

Martin, C.L., Parsons, C.K. and Bennett, N. (1995), “The influence of employee involvement in program membership during downsizing: attitudes toward the employer and the union",Journal of Management, No. 21, pp. 879-890.

Mayer, R. C., Davis, J.H. and Schoorman, F.D., (1995), "An integrative model of organizational trust", Academy of Management Review, Vol. 20, pp. 709-734.

Morrison, E.W. and Milliken, F.J. (2000), "Organizational silence: A barrier to change and development in a pluralistic world", Academy of Management Review. Vol. 25, pp. 706- 725.

Patchen, M. (1970), Participation, Achievement, and Involvement on the Job. Prentice-Hall, Englewood Cliffs, CA.

Pinder, C; Harlos, K.P. (2001). Employee silence: quiescence and acquiescence as responses to perceived injustice. Research in personnel and human resources management, Vol.20, 331-369.

Rhee, Jaehoon. Alisher Tohirovich Dedahanov , (2015),"Examining the relationships among trust, silence and organizationalcommitment", Management Decision, Vol. 53 Iss 8

Robinson, S.L. (1996), "Trust and breach of the psychological contract", Administrative Science Quarterly, Vol. 41, pp. 574-599.

Shockley-Zalabak, P., Ellis, K. and Winograd, G. (2000) "Organizational trust: What it means, why it matters", Organizational Development Journal, Vol. 18, pp. 35-49. 
Tan, H.H. and Tan, C.S. (2000), "Toward the differentiation of trust in supervisor and trust in organization", Genetic, Social, and General Psychology Monographs, Vol. 126, pp. 241-260.

Tsai, M., and Young, M (2010), "Anger, fear, and escalation of commitment", Cognition and Emotion, 24 (6), pp.962-973.

Tsui, A., Pearce, J.L., Porter, L.W. and Tripoli, A.M. (1997), "Alternative approaches to the employee-organization relationship: Does investment in employees pay off?", Academy of Management Journal, Vol. 40, pp. 1089-1121.

Van Dyne, V.L., Ang, S. and Botero, I. (2003), "Conceptualizing employee silence and employee voice as multidimensional constructs", Journal of Management Studies, Vol. 40, pp. 1360-1392.

Wang, Y. and Hsieh, H. (2013), "Organizational ethical climate, perceived organizational support, and employee silence: A cross-level investigation", Human Relations, Vol. 66, pp.783-802.

Wong, K.E. (2005), "The role of risk in making decisions under escalation situations", Applied Psychology: An international Review, Vol. 54, pp.584-607.

Yang, J. and Mossholder, L.W. (2010), "Examining the effects of trust in leaders: A basesand- foci approach", The Leadership Quarterly, Vol. 21, pp. 50- 63. 